\title{
NOTES
}

\section{The Legal Limits of Personal Liberties in Time of War}

Policing of the home front in time of war necessarily involves an extension of governmental control over the individual. The extent of the need for such control is measured by the exigencies of the conflict itself. However, the extent of the authority under which such control may be exercised is fixed by the Constitution; broadly speaking, by the "war powers" on the one hand and the Bill of Rights on the other. The problem confronting legislators and courts is that of providing all necessary wartime controls and at the same time reconciling the restraints inherent in the exercise of the war powers with the freedom which those powers are invoked to defend.

The Constitution guarantees freedom of religion, speech, press and assembly, ${ }^{1}$ protects against unreasonable searches and seizures, ${ }^{2}$ safeguards due process of law ${ }^{3}$ and trial by jury, ${ }^{4}$ forbids involuntary servitude. ${ }^{5}$ On the other hand, Congress has power not only to declare war but also "to make all laws which shall be necessary and proper" for its prosecution. ${ }^{\circ}$ And even the most primary of civil rights, habeas corpus, may be suspended "when in Cases of Rebellion or Invasion the public Safety may require it." ?

Since in the prosecution of war certain repressive measures which would be deemed dictatorial in times of peace ${ }^{8}$ are indispensable, it is pertinent to inquire into the nature of the Constitutional authority under which they may be invoked, the scope of such measures and their relation to the evils they are designed to correct, their effect upon the liberties guaranteed by the Bill of Rights, the judicial tests which may be applied to their interpretation, and the public policies which should guide their administration.

\section{The Bill of Rights}

It is important to note the scope of the Bill of Rights as shown by the decisions delimiting the liberties thereunder, for only in this way can it be determined in what manner the first ten amendments restrict or otherwise affect the measures which may be taken for the public safety. These are most conveniently reviewed under their traditional classifications.

\section{Freedom of Religion}

In the recent case of Minersville School District $v$. Gobitis ${ }^{9}$ the Supreme Court of the United States held that where there is a conflict of religious convictions and the political concern of society, the citizen is not relieved from the discharge of his political responsibilities. The social interest here held paramount to religious liberty is the "cohesive senti-

I. U. S. Const. Amend. I.

2. U. S. Const. Amend. IV.

3. U. S. CoNST. AMEND. V.

4. U. S. Const. Amend. VI.

5. U. S. Const. AMrend. XIII.

6. U. S. Const. Art. I, \&8 (II), (I8).

7. U. S. CoNsT. Art. I, \$9 (2).

8. "Only the emergency that makes it immediately dangerous to leave the correction of evil counsels to time warrants making any exception. . . ." Mr. Justice Holmes dissenting in Abrams v. United States, 250 U. S. 6I6, 630 (I9I9).

9. 310 U. S. 586, 127 A. L. R. 1493, I502 (1940). See Supp. (1940) I BmL of RIGHTS REv. No. I (reprint of brief filed amici curice by Bill of Rights Committee, A. B. A.). 
ment" of nationalism sought through a compulsory flag salute in the schools: On the authority of this case, it would appear that when the far greater interest of national existence itself is at hazard the court would not hesitate to uphold any measure restraining religious liberty which bears any reasonable relation to the national war effort.

\section{Free Speech and Free Press}

In the first sedition case of World War I, Schenck v. United States, ${ }^{10}$ Mr. Justice Holmes spoke for a unanimous court in laying down the famous "clear and present danger" test:

"The question in every case is whether the words used are used in such circumstances and are of such a nature as to create a clear and present danger that they will bring about the substantive evils that Congress has a right to prevent." 11

The inadequacy of this test as a judicial yardstick is demonstrated by the fact that Mr. Justice Holmes himself dissented in most of the cases applying it. ${ }^{12}$ A more objective test, namely that speech should be free so long as it stops short of direct incitement to law-breaking, was laid down by Judge Learned Hand, although on statutory rather than constitutional grounds, in Masses Publishing Co. v. Patten, ${ }^{13}$ but this view was rejected by the Circuit Court. ${ }^{14}$ In the present state of the law, it cannot be said with certainty what expressions of opinion may be held unlawful, for "it is a question of proximity and degree." Is In an "all-out" war in which propaganda is a major weapon even idle gossip might meet the "clear and present danger" test. Since the substantive evil would be the furnishing of useful information or the dissemination of enemy propaganda, such problems of intent as arise might be surmounted by the doctrine of "constructive" 16 intent or the legislative mechanism of "irrebuttable presumption" of intent, although the validity of the latter is highly doubtful.17

However, there is a point at which there is not only a social interest ${ }^{18}$ but a military advantage in free discussion. First, the danger of giving aid to the enemy must be weighed against the danger of impairing public morale; second, public criticism of the conduct of the war is an essential check upon profiteering, official blundering, and deficiencies of leadership. ${ }^{10}$

I0. 249 U. S. 47 (I9I9).

II. Id. at 52 .

12. Pierce v. United States, 252 U. S. 239 (I920); Schaefer v. United States, 25 I U. S. 466 (1920); Abrams v. United States, 250 U. S. 616 (1919).

I3. 244 Fed. 535 (S. D. N. Y. I9I7).

I4. 246 Fed. 24 (C. C. A. 2 d, 1917).

15. Schenck v. United States, 249 U. S. 47,52 (I919), cited notes Io, II supra.

I6. Schaefer v. United States, $25 \mathrm{I}$ U. S. 466 , 479 (I920); Abrams v. United States, 250 U. S. 6I6, 62I (I9I9), cited note I2 supra.

I7. Henier v. Donnan, 285 U. S. 312 (1932) (irrebutable presumption held to create a substitute for proof in violation of Fifth Amendment), 31 MICH. L. REv. I35, 4I YALE L. J. 906; Schlesinger v. Wisconsin, 270 U. S. 230 (I926) (conclusive presumption in state tax law held violative of Fourteenth Amendment); 9 WIGMORE, EVIDENCE (3d ed. I940) § 2492.

18. "I think that the judges themselves have failed adequately to recognize their duty of weighing considerations of social advantage. The duty is inevitable, and the result of the often proclaimed judicial aversion to deal with such considerations is simply to leave the very ground and foundation of judgments inarticulate, and often unconscious. ." Holmes, The Path of the Law (1897) ro HARv. L. REv. 457, 467.

I9. "The First Amendment protects two kinds of interest in free speech. There is an individual interest, the need of many men to express their opinions on matters vital to them if life is to be worth living, and a social interest in the attainment of truth, so that the country may not only adopt the wisest course of action but carry 
While these factors are intangible, they must be taken into account in appraising "clear and present danger," and to that extent they may be held to modify the war powers. ${ }^{20}$ But there is little reason to believe that, if these conditions are met, the Supreme Court will deny Congress the right to impose such restraints upon free speech as it deems necessary to the successful prosecution of the war. ${ }^{21}$

In the free press category we may include radio, telegraph, motion pictures and all other electrical or mechanical means of communication. The rationale of the free speech cases applies to all of them. There is ample judicial precedent for restriction upon communications in time of war. ${ }^{22}$ Publication of military information valuable to the enemy necessarily represents a danger which is both "clear" and "present." 23 Discussion of war policies presents a different problem, but even where the Holmes test is not met it should be remembered that the government may effectively suppress any newspaper or periodical it wishes by withdrawing the privilege of the mails. ${ }^{24}$ The right to distribute by other means would presumably remain, but how useful it would be in practice is highly problematical. Radio stations, which hold their licenses as a matter of grace and not of right, are subject to strict government control, as are the telephone and telegraph, through the Federal Communications Commission. Motion pictures, subject to censorship even in time of peace, might expect to be quickly suppressed if their tendencies were considered even remotely harmful.

\section{Freedom of Assembly}

This right, it should be remembered, is always subject to the common law strictures against unlawful assembly, which may be held to encompass a wide variety of circumstances. However, in De Jonge $v$. Oregon ${ }^{25}$ it was held that a state statute, prohibiting meetings sponsored by persons advocating violent overthrow of government, violated the due process clause of the Fourteenth Amendment. ${ }^{28}$ But it was stated in Herndon $v$.

it out in the wisest way. This social interest is especially important in war time." Chafee, Freedom of Speech in War Time (I9I9) 32 Harv. I. REv. 932, 958. See also Pound, Interests of Personality (IgI4) 28 HARv. L. REv. 445, 453-456.

20. "In every case, therefore, where legislative abridgment of the rights is asserted, the courts should be astute to examine the effect of the challenged legislation. : : . And so, as cases arise, the delicate and difficult task falls upon the courts to weigh the circumstances and to appraise the substantiality of the reasons advanced in support of the regulation of the free enjoyment of the rights." Schneider v. State, 308 U. S. I47, I6I (I939) (involving peace-time handbill ordinance).

2I. In World War I such restraints were not considered limitations upon the Bill of Rights. REPORT OF THE ATTORNEY GENERAL OF THE UNITED STATES (IgI8) 20: "This department throughout the war has proceeded upon the general principle that the constitutional right of free speech, free assembly, and petition exist in war time as in peace time, and that the right of discussion of governmental policy and the right of political agitation are most fundamental rights in a democracy."

22. Pierce v. United States, 252 U. S. 239 (I920) ; Abrams v. United States, 250 U. S. 616 (Igrg); Frohwerk v. United States, 249 U. S. 204 (I919); Schenck v. United States, 249 U. S. 47 (I9I9).

23. But note that if the doctrine of constructive intent or irrebutable presumption applied an individual publishing even a local weather report might be criminally liable.

24. Masses Publishing Co. v. Patten, 246 Fed. 24 (C. C. A. 2d, I9I7).

25. 299 U. S. 353 (I937), 25 CALIF. L. REV. 496, 4 U. OF CHI. L. Rev. 489, 37 Cor. L. REv. 857, 50 HARV. L. REv. 689, Note (I937) I4 iN. Y. U. L. Q. REV. 369 ; see Spencer, Criminal Syndicalism (I937) I6 ORE. L. REV. 278; (1937) 46 YALE L. J. 862. (1939).

26. See also Hague v. Committee for Industrial Organization, 307 U. S. 496 
Lozery ${ }^{27}$ that restrictions upon freedom of assembly were justified where there was "a reasonable apprehension of danger to organized government," ${ }^{28}$ and that such restrictions were proper if they had "appropriate relation to the safety of the state." 29

\section{The Other "Freedoms"}

Taken together, the decisions of the Supreme Court which involve civil liberties leave wide latitude for such legislation as Congress may consider necessary to the war effort. ${ }^{30}$ Other Constitutional guarantees are similarly circumscribed. The right to bear arms ${ }^{31}$ is virtually a dead letter. $^{32}$ The search and seizure provision likewise lacks adequate enforcement machinery; ${ }^{33}$ difficulties inherent in obtaining redress seriously curtail its usefulness. Star Chamber proceedings leading to internment of enemy aliens in concentration camps seem far removed from the layman's concept of due process. ${ }^{34}$ And the average citizen would have some difficulty in distinguishing compulsory military service from "involuntary servitude." 35 As for habeas corpus, the Supreme Court denied that President Lincoln had the power to suspend it in a non-military zone, ${ }^{36}$ but the fact remains that he did it. In general, it may be said that there appears to be little likelihood that any measure functionally necessary to the conduct of the war will be stricken down on the ground that it transgresses upon civil liberties.

\section{The Federal Statutes}

Since the Supreme Court has interposed no serious obstacles, what weapons has the Congress created for the war against the "Fifth Column"? Treason, of course, is foremost in any list of crimes against the state, ${ }^{37}$ and applies both to citizens and aliens, ${ }^{38}$ but judicial construction has limited its application ${ }^{89}$ and the doctrine of "constructive" 40 treason has never found acceptance here. ${ }^{41}$ Conspiracies to overthrow the government

27. 301 U. S. 242 (I937); see Heller, Freedom of Assembly (I940) 25 MARQ.

I. REV. I, 5 .

28. 30T U. S. 242,258 (I937).

29. Ibid.

30. Salus republice suprema lex, a dangerous aphorism, lies close to the surface of the judicial rationale. See Note (1928) 42 HARV. L. Rev. 265.

3I. U. S. CoNST. AMEND. II.

32. See Chafee, Arms, Right to Bear (I930) 2 Encyc. Soc. Scr. 209.

33. 2 Willoughey, Constitutional LAW (2d ed. I929) $\$ 720 ; 8$ WIGMORE, EVIDENCE (3d ed. I940) $\$ \$ 2 I 83,2184$; LASSON, HISTORY AND DEVELOPATENT OF THE Fourth AMrendment (I937); Fraenkel, Concerning Searches and Seizures (I92I) 34 HARV. L. REv. 361.

34. U. S. Const. AMend. V. No person shall be . . . deprived of . . . liberty . without due process of law.

35. Selective Draft Law Cases, $245 \dot{U}$. $\stackrel{\text { S. }}{ } 366$ (1918). There was no conscription in the United States prior to the Civil War, and under the first statute service could be avoided by payment.

36. Ex Parte Milligan, 4 Wall. 2 (U. S. I866). (I934).

37. U. S. CoNST. Art. III $\S 3 ; 35$ STAT. IO\$8 (Ig09), I\& U. S. C. A. $\$ \S I, .2$

38. Carlisle v. United States, I6 Wall. I47 (U. S. I872).

39. 3 WHARTON, CRIMINAL LAW (12th ed. I932) \$\$ 2159, 2160; cf. United States v. Hanaway, 26 Fed. Cas. No. 15,299 (C. C. E. D. Pa. I85I). But see Homestead Case, I Pa. Dist. 785 (1892) (grand jury charge); Ex Parte Bollman \& Swarthwout, 4 Cranch 75 (U. S. I807) ; United States v. Greathouse, 26 Fed. Cas. No. I5,254 (C. C. N. D. Cal. I863); MIILER, CRrarinal LAW (I934) § I724

40. 2 STEPHen, History OF THE CRIMINAL LAW OF ENGLAND (I883) c. 23. But see Bridges, $A$ Suggestion Toward a New Definition of Treason (1939) 30 J. CRIN. L. 470 .

4I. It is suggested that this is because the same result is achieved through legis-

lation. See Frohwerk v. United States, 249 U. S. 204, 210 (I9I9). 
of the United States by force have been crimes since long before the last World War. ${ }^{42}$ The common law rules of criminal attempt and incitement still apply, but the principal remedies are statutory. A recent study of free speech ${ }^{43}$ lists fifteen Federal statutes on interference with the government, three on objectionable foreign influences, three on aliens, three on the use of the mails, two on importation and interstate transportation, and three governing search warrants, all bearing in some manner upon the Bill of Rights.44 But the list ends in I940, and since that time Congress has been far from idle. In I94I, up to the outbreak of war on December 7, it enacted seven new statutes dealing with "subversive influences," ${ }^{45}$ and in nineteen different appropriation acts provided that the appropriations thereunder were not to be used to pay persons or members of organizations advocating forcible overthrow of the government. ${ }^{46}$

In World War I the government's principal weapons against internal dissidence were the Espionage Act of 1917 , which is still in effect, ${ }^{47}$ and the Sedition Act of I918, ${ }^{48}$ which was repealed in I921. ${ }^{49}$ In World War II it has, as a supplement to the former and a more drastic counterpart of the latter, the Alien Registration Act of $1940.0^{50}$ The title of this statute is misleading, for in addition to its registration function it gives the government broader powers over citizen and alien alike than it enjoyed even under the Espionage Act of I9I7. In effect it is an omnibus "antisubversion" statute.

The Act makes it unlawful to interfere with the armed forces with intent to influence their loyalty, morale or discipline, either by advice and counsel or by means of written or printed matter. ${ }^{51}$ It makes unlawful the production and distribution of written or printed matter advocating the violent overthrow of the government, as well as membership in or association with organizations having such objectives, knowing the purposes thereof. ${ }^{52}$ Attempts or conspiracies to commit the prohibited acts are

42. Rev. Stat. §5336 (1875) ; 35 Stat. I089 (Ig09), I8 U. S. C. A. § 6 (I934). 43. Chafee, Free Speech in the United States (I94I).

44. Id. at $572-574$.

45. Act of June 20, I94I, 55 STAT. 252, Pub. L. II3 (immigration visas, etc., may be refused aliens likely to endanger public safety of United States); Act of June 2I, I94I, 55 STAT. 252, 253, Pub. L. II4 (President authorized to restrict immigration or emigration of aliens during war or emergency); Appropriation Act of June 28, I94I, 55 STAx. 292, Pub. I. I35 (\$100,000 for investigation of Federal employes who are members of subversive organizations, by F. B. I.); Emergency Relief Appropriation Act of July I, I94I, 55 STAT. 402, Pub. L. I43 § I0 (f) (employment of Communists or members of Nazi Bund on work relief prohibited) ; Act of August II, I94I, 55 STAT. 6I6, Pub. L. 203 (plant protection force to investigate sabotage or subversive activity in and to naval shore establishments); Act of August 2I, I94I, 55 Stat. 655, Pub. L. 234 (amendment to act to punish injury or destruction of war material by redefining national defense material); Act of October I3, r94I, 55 STat. 736, Pub. L. 268 (penalty provided for photographing alien registration cards).

46. Appropriations covering: Maritime Commission, 4th defense supplement, defense aid supplement, first deficiency, independent offices, fifth defense supplement, naval, War Department, Treasury and Post Office, State, Commerce, Justice, Federal Judiciary, Interior, military, relief, Agriculture, Legislative, Federal Security (Labor), District of Columbia, second deficiency, and second defense supplemental.

47. 40 STAT. 217 (19I7), 50 U. S. C. A. \$§ 3I-38 (I934).

48. 40 STAT. 553 (I9I8).

49. 4I STAT. I359, I360 (I92I).

50. 54 Stat. 670 (I940). See Legis. (I935) 35 CoL. L. Rev. 9I7 (I94I) 4 I id. I59; Oppenheimer, The Constitutional Rights of Aliens, (194I) I BIII OF RIGHTS

REv. IOO; Biddle, Wechsler and others, Symposinm on Civil Liberties (I94I) 9 Ax.

L. SCHOOL REv. 88I.

5I. Alien Registration Act. Tit. I, § I.

52. $I d . \S 2$. 
likewise made criminal, ${ }^{53}$ and written or printed matter falling within the terms of the Act is subject to seizure. ${ }^{54}$ The maximum penalty is $\$ 10,000$ fine and ten years in prison. ${ }^{55}$ The Act also provides for regulation of aliens and establishes certain new rules relative to deportations.

Apart from the routine of registration, little was heard of this statute until the outbreak of the war, but within two weeks thereafter 2886 enemy aliens, "regarded as dangerous to the peace and safety of the country," were arrested. ${ }^{56}$ In the first days of the war a few arrests of citizen suspects were made by zealous United States Attorneys. These actions were quickly recalled, and Attorney General Biddle announced that prosecutions of citizens would be conducted only upon express authorization by the Department of Justice. ${ }^{57}$ If this policy of preliminary review can be consistently followed under the stress of war conditions it may do much to soften the rigors of a statute containing many potentialities for harm.

\section{State Legislation}

It is not within the scope of this note to survey the state statutes involving the liberties of individuals. One recent summary lists twenty pages of such enactments on freedom of speech alone, ${ }^{58}$ and does not include any state laws passed since $1940 .{ }^{59}$ These statutes raise the question whether they do not impede rather than supplement the Federal government's efforts, ${ }^{60}$ and whether they may not be instruments of political oppression. They are frequently inconsistent, establishing state criteria of criminality varying both in nature and degree.

\section{Criteria of Criminality}

Federal and state legislation now in effect covers a wide variety of acts considered subversive. ${ }^{61}$ As the war proceeds, it is likely that this list will be extended. ${ }^{2}$ Bills have been offered in Congress making even remote "bad tendency" punishable, ${ }^{63}$ to the extent that it would be unlawful to think evil of the government. ${ }^{64}$ It is not inconceivable, depending upon the temper of the public and the fortunes of war, that some such

53. Id. \$3.

54. Id. $\$ 4$.

55. Id. $\$ 5$.

56. Press conference statement by Attorney General Biddle, Dec. 20, I94I; N. Y. Times, Dec. 21, 194I, \& I, p. 23.

57. Public statement by Attorney General, Dec. 16, I94I; N. Y. Times, Dec. I7, I94I, p. 24.

58. CEAFEE, op. cit. supra note 43, 575-597.

59. Adverted to in Ward, The Communist Party and the Ballot (I94r) I Brus of RIGHTS REV. 286.

60. The Attorney General asked after the declaration of war that citizens and local and state governments consult with the Federal Bureau of Investigation instead of taking "direct action" against suspected aliens. N. Y. Times, Dec. 2I, I94I, p. 22.

6I. Notes $44,45,60$ supra.

62. A number of drastic bills were on the House of Representatives calendar of December 5, two days prior to the outbreak of war, including one to establish an optional death penalty for sabotage, H. R. 2, Cong. Rec. Index No. XXIII, Vol. 87 (I94I).

63. Legis., Recent Federal Legislation Against Subversive Influences (I94I) 41 COL. I. REV. I59.

64 54 STAT. II37, II4I (I940), 8 U. S. C. A. \$705 (Supp. I94I) (refusal of naturalization); H. R. 4905, 76th Cong. Ist Sess. (March 9, 1939) (deportation of aliens); H. R. 4909, 76th Cong. Ist Sess. (March 9, I939) (ineligibility to hold government position); H. R. 4907, 76th Cong. Ist Sess. (March 9, I939) (registration of organizations), but not followed in registration law, 54 STAT. I20r (I940), I8 U. S. C. A. \$\$ I4-I7 (Supp. I94I). 
legislation may yet be enacted. Unfortunately it is not necessary to consider this problematical future, for in the Alien Registration Act we already have a new crime of "association" ${ }^{65}$ which brings us perilously close to the same result. It is a crime under the Act to belong to or be associated with an organization or group advocating violent overthrow of the government, knowing its purposes. Membership may be considered evidence of knowledge of purpose. ${ }^{68}$ Nor does it seem unlikely that affiliation with a "front" organization, so-called, might lead to the same result.67 Ironically, Congress aimed this legislation directly at the Communist Party only a few months before the U. S. S. R. became America's anti-Axis partner in the war. The lawmakers apparently assumed that the Communist Party advocated violent overthrow of the United States government, although this much-mooted point is only now on its way to determination by the Supreme Court. 68

Can anyone be punished for what he thinks? The Supreme Court has said not. ${ }^{69}$ Yet nearly 3000 enemy aliens, ${ }^{70}$ some of them lifelong residents of the United States, have been arrested under a statute that does not require that they be proved guilty of any overt act. They must depend upon the decision of the Attorney General, based in turn upon recommendations by civilian hearing boards, to determine whether they shall be released, paroled, or interned for the duration of the war. ${ }^{71}$ The hearings are secret, the suspect may or may not be permitted to attend. ${ }^{22}$ The action is not subject to judicial review. And under a technique developed during World War I even a naturalized citizen may find himself an "enemy alien," if it is decided that he made mental reservations on taking his oath. ${ }^{73}$

What of citizens? The doctrine of "association" raises the question whether membership in an organization is in itself an overt act, particularly if past membership makes one equally guilty. If it is, the rationale must rest upon a tenuous and highly technical basis. If it is not, it may well be contended that it is too late to catch a subversive individual after he has committed a disastrous overt act, and too hazardous to await an attempt, which under the law must come dangerously close to success. And even without an overt act the "clear and present danger" test might be satisfied, as in the case of a known partisan of the enemy with a notoriously violent history. Having provided that an enemy alien might be judged in Star Chamber and imprisoned without an overt act, why should not the Congress extend the same principle to citizens, since the danger to be apprehended from disloyal individuals is not affected by their citizenship

65. Alien Registration Act, 'Tit. I, §2.

66. State v. Boloff, I38 Ore. 568, 7 P. (2d) 775 (I932), 45 HARv. L. REv. 927.

67. In Pennsylvania a number of State employes were dismissed under the terms of a similar statute for alleged association with groups described as "front"' organizations for the Communist Party.

68. Schneiderman v. United States, II9 F. (2d) 500 (C. C. A. 9th, I94I), cert. filed, to U. S. L. WEEK 308I (I94I). See (I94I) 89 U. OF PA. L. REv. 823 (judicial notice of Communist Party's objectives).

69. Under the First Amendment "Congress was deprived of all legislative power over mere opinion." Reynolds v. United States, 98 U. S. I45, I64 (I878).

70. Note 56 supra. There were I,460 Japanese, I,204 Germans, 222 Italians.

7I. The Department of Justice stated that the Attorney General would render the final decision as to the disposition of each case. Note 56 supra.

72 . Id. "As a general rule, the alien concerned will be present at such hearing, though occasional exceptions may be made, especially in cases where confidential information of possible value to the enemy is involved."

73. United States v. Wursterbarth, 249 Fed. 908 (D. N. J. I9I8). 
status? ${ }^{74}$ The answer is that the citizen, too, comes within the purview of the act for the "registration" of "aliens," which provides in Section 2 that "it shall be unlawful for any person . . ."

\section{The INNOCENT Bystander}

The object sought to be achieved through repressive war legislation is elimination of influences designed to help the enemy. On the basis of the experience of World War I, its effectiveness may be questioned, ${ }^{75}$ and the results may not justify the price paid in terms of freedom sacrificed. ${ }^{70}$ This is debatable. But it is not debatable that such statutes are dangerous weapons, requiring the utmost administrative and judicial control lest they become instruments of oppression. ${ }^{77}$ The experience of the last war in this respect was not a happy one. ${ }^{78}$

Because of the human factor involved in the administration of all law, individual injustice is bound to result from the application of laws dealing with the intangibles of "subversive" activity. This is particularly true in the absence of any test which might be applied by judges and prosecutors in dealing with the cases before them. We have seen that the "clear and present danger" criterion breaks down in practice. Judge Hand's test, ${ }^{79}$ it is true, furnishes a tool which judges and juries can use. But it is after all only the common law test of incitement, and the recent flood of new statutes on "subversion" indicates that this is not what the Congress wanted. It wanted action, and action before the danger could become either "clear" or "present," so long as it lurked in the vicinity.

Even so, every possible effort consistent with the proper conduct of the war should be made to protect the innocent. Since their greatest danger is from blind public frenzy the method of public education, suggested in time of peace by the head of the Civil Liberties division of the Department of Justice, ${ }^{80}$ has much to commend it. But in time of war it is not even desirable, for the public must be educated to hate the enemy. Under such circumstances it is unrealistic to expect an aroused public to act with judicial impartiality when it suspects disloyalty. Likewise, it is to be expected that state legislatures will enact "shotgun" legislation, and that state officials and courts will reflect local hysteria in administering such laws. ${ }^{81}$

Since this danger of injustice is apparent, it is pertinent to inquire whether all matters dealing with subversive activity should not be handled by Federal authorities. The Attorney General has in effect asked that this be done. ${ }^{82}$ Centralized responsibility and control, establishing uniformity of administration and policy, certainly seem desirable. The war power resides in the Congress, and since treason against the United States is not

74. It was argued by Representative Smith of Virginia that the House should make no distinction between citizens and aliens, as the danger was the same in either case. 84 CONG. REC. I0452 (I939).

75. С

76. Loewenstein, Legislative Control of Political Extremism in European Democracies (I938) 38 CoL. L. REv. 59I.

77. Chafee, Freedom of Speech in War Time (1919) 32 HARv. L. Rev. 932, 960.

78. Legis. (1935) 35 Cor. L. REv. 9I7, 9 Ig.

79. Note 13 supra.

80. Schweinhaut, The Civil Liberties Section of the Department of Justice (I94I) I BII, of RigHis REv. 206, 2I6.

8I. O'Brian, Assistant to the Attorney General of the United States, reporting on public hysteria, (I9I9) 52 N. Y. BAR ASSN. REP. 28I.

82. Note 60 supra. 
punishable by the states, ${ }^{83}$ there seems no reason why any other interference with the war power should be. ${ }^{84}$ The recent case of Hines $v$. Davidowritz, ${ }^{85}$ invalidating the Pennsylvania Alien Registration Act, looks in this direction. If Congress has not already enacted all legislation necessary to deal with the problem of subversive activities nationally, it certainly should do so. If it has, then the constitutionality of State legislation overlapping the same field would appear doubtful under the doctrine enunciated in the Davidozeritz case.

During World War I there were some persons, guilty of no crime whatever, who without any cause other than war hysteria were the victims of mob violence, ${ }^{86}$ ill-advised prosecutions, ${ }^{87}$ prejudiced juries ${ }^{88}$ and biased judges. ${ }^{80}$ With such persons the time element is essential, for it avails them little to learn from the Supreme Court, after the war is over, ${ }^{80}$ that their rights were violated.

If they are suspected, however erroneously, how are they to be protected from the mob? The inadequacy of local authorities to deal with such situations has been made notorious by the tragic history of lynching in the United States. Yet mob psychology is such that if the authority of the sovereign is asserted firmly, and quickly, the danger quickly subsides. In Pennsylvania the dispatch of uniformed State policemen into trouble zones as "observers," under orders to do nothing except to make themselves conspicuous unless a breach of the peace is committed in their presence, proved highly effective when attempted experimentally in 1937-38. There seems no reason why a similar technique would not be feasible on a national scale; in fact something of the kind has been done through the use of "token" detachments of soldiers to preserve order at strike-bound defense plants.

Where legal process is to be invoked it seems desirable to obtain the cooperation of State authorities to the end that prosecutions be brought under Federal law, as noted supra, and where this is not possible the validity of state statutes might properly be questioned.

Obviously prejudice on the part of juries cannot be avoided simply by transferring prosecutions from the state to the Federal courts, but where trial by jury would be ineffective in safeguarding the rights of the accused it may be waived. Where administrative officers find the facts, as in deportation proceedings, it may be that the application of the facts to the law, as distinct from either questions of law or questions of fact, is properly a judicial function to be exercised by the courts. ${ }^{91}$

While Congress has set many legal snares for the spy, the saboteur, the enemy propagandist, the suspect alien and the disloyal citizen, it has done little to protect the innocent bystander from the forces of suspicion, hatred, distrust and vindictiveness which its necessary exercise of the war powers has set in motion.

83. People v. Lynch, II Johns. 549 (N. Y. I8I4); see Ex Parte Quarrier, 2 W. Va. 569,571 (I866).

84. See Konkel v. State, I68 Wis. 335 , I70 N. W. 715 (I919).

85. 312 U. S. 52, 73 (I94I). But see Gilbert v. Minnesota, 254 U. S. 325 (1920).

86. O'Brian, Civil Liberty in WVar Time (I9I9) 42 N. Y. BAR AsSN. REP. 275, 302.

87. Id. at 304, 305, 309.

88. CHAFEE, op. cit. supra note 43 , at $70-73$.

89. Id. at 74-79.

9o. The Supreme Court did not rule on any of the World War I statutes until long after hostilities had ended.

91. See Pound, Interpretations of Legal History (1923) I54-155; (I938) 48

YALE L. J. III. 


\section{SUMMary}

The major conclusion to be drawn from the relationship of the war powers to civil rights in time of war is that the judicial definition of personal liberties will be subject to such adjustment as the safety of the state requires. A corollary to this conclusion is that, in the process of this adjustment, much individual injustice may result from the lack of any practical standard of criminality and the consequent resort to the "bad tendency" or remote causation theory. Procedural reforms such as elimination of overlapping State and Federal jurisdictions, centralized control of prosecutions, and more expeditious judicial review, should help to minimize this danger. But it will not be eliminated entirely so long as the law's vaunted certainty is belied by such tests as that of "clear and present danger" at a time when to the average individual the most obscure political heresies may be "clear" subversion and the remotest apprehension may be a "present" and appalling danger.

J. $S$.

\section{The Non-Recognition of the U. S. S. R. and Its Effect Upon the Statute of Limitations}

Recognition is the means whereby a new nation, whether originating in peaceful political change or in the chaos of revolution, is admitted to that select, though cosmopolitan group, the Family of Nations. Nonrecognition is ostracism, and has important legal consequences.

Recognition can neither bring a new government into existence, nor keep it from coming into being. Existence is a matter of fact. ${ }^{1}$ However, recognition can greatly affect the operation of that fact.

There is no international comity, ${ }^{2}$ no reciprocity of obligation, between a non-recognized and a non-recognizant government. ${ }^{8}$ The unrecognized sovereign is precluded from using the courts of the non-recognizant country, ${ }^{*}$ although fortunately it does receive the same immunity from suit

I. Goeber, The Recognition Policy of the United States (I9I5) 46; r Hack-

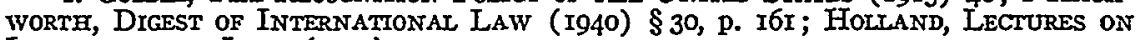
INTERNATIONAL LAW (1933) 9 I.

2. "Comity" is, at best, a far from concrete term, but it is useful as being comprehensive. A helpful definition is that of Mr. Justice Baldwin in Fischer, Brown \& Co. v. Fielding, 67 Conn. 91, 108 (1895):

"What is termed the comity of nations is the formal -expression and ultimate result of that mutual respect accorded throughout the civilized world by the representatives of each sovereign power to those of every other, in considering the effects of their official acts. Its source is the sentiment of reciprocal regard, founded on identity of position and similarity of constitutions."

3. "The entrance of the state into the international statehood, however, depends entirely upon the recognition by those states already within this circle. Whatever advantages membership in this circle may confer, and whatever duties it may impose, do not fall upon the new state until its existence is generally recognized by the states already within the international circle." WIISON \& TUCKER, INTERNATIONAL LAw (8th ed. 1922) 49. See also POMreroy, InTERNATTONAL LAW (1886) 265.

4. Republic of China v. Merchant's Fire Assurance Corp. of New York, $30 \mathrm{~F}$. (2d) 278 (C. C. A. 9th, 1929); The Penza, 277 Fed. 294 (N. D. Cal. I920); R. S. F. S. R. v. Cibrario, 235 N. Y. 255, I39 N. E. 259 (I923); City of Berne v. Bank of England, 9 Ves. Jr. 347 (I804).

There is no doubt that a recognized foreign sovereign may sue in the courts of a recognizant nation. The Sapphire, Ir Wall. I64 (U. S. I870); King of Prussia v. Kuepper, 22 Mo. 550 (I856) ; Republic of Honduras v. De Soto, II2 N. Y. 310, Ig N. E. 845 (I889); Hulett \& Co. v. King of Spain, I Dow and Clark I69, 6 Eng. Rep. R. 488 (I828) ; HERVEY, LEgAI EFFECTS OF RECOGNITION IN INTERNATIONAI LAW (I928) II2. 
accorded to all sovereigns. ${ }^{5}$ As a result of its inability to sue the sovereign is often unable to protect many of its interests, and may thereby lose important substantive rights. ${ }^{6}$ Its citizens may not be accorded the privileges and immunities granted those of a recognized government; its instrumentalities may be unable to function properly. ${ }^{7}$ Hence, recognition means much to a newly organized government. ${ }^{8}$ The Soviet government of Russia is an excellent illustration of the effect of both recognition and nonrecognition.

In I9I7 Russia was a hotbed of revolution and political change. Within nine months its government changed hands twice. On March 16 , I9I7, the old Russian Imperial Government was overthrown and succeeded by the Provisional Government, which was recognized by the United States six days later. On November 7, I9r7, the Provisional Government was overthrown and succeeded by the Union of Soviet Socialist Republics. The U. S. S. R. has remained in power to the present day but was not recognized by the United States until November I6, I933. ${ }^{\circ}$ This policy of non-recognition, pursued for sixteen years, has led to much difficulty in American courts, ${ }^{10}$ whose attitude toward foreign governments must be determined by that of the executive and legislative branches. ${ }^{11}$

Due to the established rule that an unrecognized foreign sovereign cannot appear as plaintiff in the courts of the non-recognizant government ${ }^{12}$ the U. S. S. R. was unable to exercise any right of action accruing against the United States or a citizen thereof until its recognition in I933. One of the problems resulting is this: Did the statute of limitations start to run against the Soviet government from the time the right of action accrued, or is it either not applicable to a foreign sovereign or tolled by that sovereign's disability to sue?. The United States Supreme Court in Guaranty Trust Company v. United States ${ }^{13}$ and the United States District Court in U.S.S.R. v. National City Bank ${ }^{14}$ were recently presented with this

5. A recognized foreign sovereign may not be sued without its consent. Oetjen v. Central Leather Co., 246 U. S. 297 (1918) ; Porto Rico v. Rosaly, 227 U. S. 270 (19ז3); The Schooner Exchange v. M'Faddon, 7 Cranch. Ir6 (U. S. 1812).

The question of whether or not a non-recognized foreign sovereign could be sued without its consent has recently been before the New York courts. They have held it could not. Veovodine v. Government of the Commander-in-Chief of the Armed Forces of the South of Russia, 232 App. Div. 204, 249 N. Y. Supp. 644 (I93I); Nankivel v. Omsk All-Russian Government, 237 N. Y. I50, I42 N. E. 569 (I923);

Wulfsohn v. R. S. F. S. R., 234 N. Y. 372, 138 N. E. 24 (I923).

This immunity has been extended to sovereign property. The Schooner Exchange v. M'Faddon, 7 Cranch. II6 (U. S. I8I2); The Parlement Belge, (1880) I. R. 5 P. D. 197 .

6. See U. S. S. R. v. National City Bank, 4I F. Supp. 353, 355 (S. D. N. Y. I94I); HERVEY, LeGaI EFFECTS OF RECognition IN INTERNATIONAI LAW (I928) II2. 7. See Dickinson, The Recognition of Russia (I93I) 30 MrCH. L. REv. I8r.

8. For a discussion of recognition see Sir John Fischer Williams, Recognition (I929) I5 TRANSACTIONS OF THE GROTIUS SOCIETX. 53.

9. For a brief historical summary of the Russian situation, see Guaranty Trust

Co. v. United States, 304 U. S. 126, I38 fn. 4 (1938). For editorial comment see (I934) 28 AM. J. INT. L. 90.

I0. See (1932) 26 AM. J. IN1: L. 26I; Dickinson, The Recognition of Russia (I93I) 30 MICH. L. REv. I8I.

II. Luther v. Borden, 7 How. I, 42 (U. S. I849); Rose v. Himely, 4 Cranch. 24I, 272 (U. S. 1808) ; R. S. F. S. R. v. Cibrario, 235 N. Y. 255, I39 N. E. 259 (ig23) ; Pomeroy, International Law (I886) 3I2; PUente, International Law (I928) 26.

12. Preobazhenski v. Cibrario, I92 N. Y. Supp. 275 (Sup. Ct. I922). Other cases cited note 4 sipra.

I3. 304 U. S. 126 (I938). Commented on in (1938) 32 AM. J. INT. L. 542; (I939) 37 MICE. L. Rev, 93I.

I4. 4 I F. Supp. 353 (S. D. N. Y. I94I) 90 U. of PA. L. Rev. 364. 
problem. Both held the statute barred the action regardless of the sovereign's disabilities.

The Guaranty Trust Company case was decided on the ". . . principle that the rights of a sovereign state are vested in the state rather than in any particular government which may purport to represent it . . .."15 Since the recognized Provisional Government of the Russian state always had the right to enforce the state's claims, said the court, there was no reason to toll the statute- the state had never been under a disability.

U. S. S. R. v. National City Bank followed this reasoning and added the policy consideration that, if the statute of limitations was merely tolled and did not run during the period of non-recognition, ". . . one of the most effective sanctions of non-recognition would lose most of its value." 16

Two previous cases, George W. Cook v. Mexico ${ }^{17}$ and Collac $v$. Yugoslav State, ${ }^{18}$ reached a contrary conclusion. Both cases were argued before international tribunals ${ }^{10}$ but unfortunately the available reports do not give the reasoning whereby the conclusion was reached.

These cases form the nucleus of our discussion.

\section{LEGAL TheorIEs INVOLVED}

International relations are matters of politics and diplomacy. They are controlled and regulated by the executive and legislative branches of the government, not by the judiciary. It is uncontested that recognition or non-recognition is a question of policy determinable only by the political branches of the government, with such determination binding upon the courts. $^{20}$ However, legal problems inevitably arise involving international relations and the courts must decide them.

It is the duty of the judiciary to give effect to the purpose behind political determinations. Policy is therefore a primary consideration. But, through precedent and a desire to promote stability, the judiciary has evolved theories upon which it may proceed with relative firmness.

\section{a. Tolling the Statute of Limitations}

The most obvious theory with which the Soviet government and its assignees would attempt to avoid the effects of the statute of limitations is that of tolling the statute.

The statute of limitations is a defense which may be raised as a bar to an action not brought within the time required by the statute. Its purpose is to prevent the bringing of actions after so much time has elapsed that parties and evidence are scattered and unobtainable. ${ }^{21}$

I5. 304 U. S. 126, 137 (1938).

I6. 4 I F. Supp. 353,355 (S. D. N. Y. I94I):

17. (1927-1928) ANNUAL DigesT, Case No. I74. The editor's note to this case states, "What seems to be generally admitted is that national statutes of limitation do not in themselves constitute a bar to international action."

A fuller report of this case may be found in (I928) 22 AN. J. INT. L. I8g.

Dicta favoring the application of the statute of limitations to a foreign government may be found in Lehigh Valley RR. v. State of Russia, 2I F. (2d) 396, 400 (1927) ; United States v. Brown, 247 N. Y. 211,218, I60 N. E. I3, I6 (I928). But see United States v. Harpootlian, 24 F. (2d) 646,648 (C. C. A. 2d, I928); Bowers v. N. Y. \& Albany Literage Co., 273 U. S. 346, 350 (1927).

18. (1929-1930) ANNuAT Digest, Case No. I21.

19. Respectively the United States and Mexico General Claims and the HungaroYugosiav Mixed Arbitral Tribunal.

20. If the courts do not hold themselves bound by such determination, they are dangerously intermeddling with matters of foreign policy clearly outside their province. See cases cited note II supra.

2r. The statute of limitations is considered a meritorious defense. United States v. Oregon Lumber Co., 260 U. S. 290 (1922); Bell v. Morrison, I Pet. 35I, 360 
This commendable purpose is, however, overbalanced when we are presented with a situation wherein the party against whom the statute ran was unable to bring suit through no fault of his own. The obvious injustice that would result to such a suitor, if he were now barred because of his former inaction, is prevented by tolling the statute.

The argument advanced by those who would toll the statute here is based on an analogy between a disability to sue because of non-recognition and other disabilities to sue wherein the statute is tolled. Infancy, insanity and imprisonment are universally accepted as tolling disabilities. ${ }^{22}$ Others are enumerated in the various limitation statutes. ${ }^{23}$ The courts seem loath to lengthen their number. The prevailing attitude was expressed by the Colorado court in Miller v. Industrial Commission, ${ }^{24}$ where it was said:

"Unless specific exception is made in the statute of limitations in favor of those under disability, courts are without power to add such exception."

It was therefore easy for the courts in the Guaranty and National City Bank cases to say that the statute of limitations must apply as a procedural rule of the forum ${ }^{25}$ and bar the action. A relaxation of this rigid attitude could easily have resulted in tolling the statute as to the Soviet government. ${ }^{28}$

Perhaps, for a different reason, the defense of the statute of limitations should not be available to the defendant in the instant situation. It seems clear that the defendant who has forced the plaintiff to delay in bringing his action cannot afterward raise the bar of the statute as a defense. ${ }^{27}$ Here, the government of the United States prevented the Soviet government from bringing suit by refusing recognition. Our government is com-

(U. S. I828) ; Lilly-Brackett Co. v. Sonnemann, I57 Cal. I92, I06 Pac. 715 (I9I0)

(reviewing the authorities); Story, CONFLICT of LAws (8th ed. I883) 793.

22. See 2 Wood, Limitation of Actions (4th ed. 1916) c. 22, p. 1069. A typical statute is N. Y. CIv. PrAC, ACT (Cahill, 6th ed. I93I) $\$ 60$.

There are usually some qualifications. New York, for instance, does not permit the statute to be tolled by any disability other than infancy for longer than five years.

23. See 2 Mass. Gen. Laws (1932) c. 260; 4 Mont. Rev. Codes (I935) c. 27 ; I Mo. REv. STAT. (I929) art. 9.

24. I06 Colo. 364, 367, I05 P. (2d) 404, 405 (I940). See also Richardson v. Mertens, I75 Ala. 309, 57 So. 720 (I9I2) ; Powell v. Koehler, 52 Ohio St. I03, 39 N. E. I95 (1894); Warfield v. Fox, 53 Pa. 382 (1866).

25. The statute of limitations is the applicable law of the forum. See Hanger v. Abbott, 6 Wall. 532, 538 (U. S. 1867) ; McMerty v. Morrison, 62 Mo. 140, I43 (1876) ; Miller v. Brenham, 68 N. Y. 83, 87 (I877) ; 3 BEALE, THe CoNflict of Laws (1935) § 693.I, p. 1620 .

The statute of limitations is a rule of procedure. M'Elmoyle v. Cohen, r3 Pet. 3II, 327 (U. S. I839); Townsend v. Jemison, 9 How. 407, 413 (U. S. I850).

This means it merely bars the remedy but not the right. [See Michigan Bank v. Eldred, I30 U. S. 693, 696 (r889) ; Townsend v. Jemison, 9 How. 407, 4I3 (U. S. I850); Van Schuyver v. Hartman, I Alaska 43I, 432 (I902)], which may well lead to a different result than that reached in foreign jurisdictions where the statute is a substantive rule. The difference between the substantive and procedural views is discussed in (19I9) 28 YAIE L. J. 492.

26. This attitude has been relaxed in certain instances, and the running of the bar has been suspended for a disability not mentioned in the statute. Inland Steel Co. v. Jelenovic, 84 Ind. App. 373, I50 N. E. 391 (1926) (war suspends statute); Sands v. Campbell, $3 \mathrm{I}$ N. Y. 344 (I865) (injunction while operative suspends statute); Garvin v. Diamond Coal \& Coke Co., $278 \mathrm{~Pa}$. 469, I23 Atl. 468 (I924) (war suspends statute); see Weaver y. Davis, 2 Ga. App. 455, 462, 58 S. E. 786, 789 (I907). Contra: Knipple v. Lipke, 300 N. W. 620 (Minn. I94I).

27. Thompson v. Phenix Ins. Co., I36 U. S. 287 (I889); Patrick v. Groves, II5 N. J. Eq. 208, I69 Atl. 70I (I934); Howard v. West Jersey \& S. S. Ry., ro2 N. J. Eq. 5I7, I4I Atl. 755 (I928). 
posed of its citizens and acts for them. Hence, the policy of non-recognition was a reflection of the will of the defendant in each of the cases before us, and it would seem more equitable not to allow him to raise the statute of limitations when it therefore ran as a result of his own actions.

Admittedly the argument is highly theoretical but no more so than some of the other arguments advanced by the courts, and the result reached by employing it seems desirable.

\section{b. The Continuing State}

"The rights of a sovereign state are vested in the state rather than in any particular government which may purport to represent it . . .."28

While in the vernacular the State and its Government are used as identical terms, there is an important distinction between them.

"The State itself is an ideal person, intangible, invisible, immutable. The Government is an agent-an instrumentality of the State,through which the will of the State is formulated, expressed and executed ...."29

This distinction is of much consequence in international law and is of especial significance in the consideration of the instant problem. The distinction is necessary if we are to have safety and stability in international dealings. The case of Russia is an excellent illustration of the point. Any transactions with Russia were consummated with the State although accomplished through the Government. Any claims resulting therefrom rested with the State, not the Government. Therefore, all those holding claims or subject to claims are protected, for if the claims rested in the Government, they would rise and fall with the Government. Any claims against the old Imperial Government, for instance, would have become valueless upon the rise to power of the Provisional Government. The claims, resting as they do, however, in the State, remain valuable and may be asserted regardless of any change in Government for the State is omnipresent and unchangeable. ${ }^{30}$

Applying this distinction to our present problem we reach the conclusion that the statute of limitations could not have been tolled because the Russian State was always represented by a government recognized and capable of bringing suit. ${ }^{31}$ The Provisional Government continued until I933 and its ambassadors were here and could prosecute suits for that government. ${ }^{32}$ This was the reasoning followed by the Guaranty Trust Company and National City Bank cases.

28. Guaranty Trust Co. v. United States, 304 U. S. 126, 137 (1938).

29. PuEnte, International Law (1928) I8. For another definition of "State" see Wheaton, Elements of International LAw (Scott ed. I936) § I7, p. 25. 30. The doctrine of continuity of States has been asserted in: The Sapphire, II Wall. I64 (U. S. I870); Gelston v. Hoyt, 3 Wheat. 246,324 (U. S. I8I8) ; Lehigh Valley RR. v. State of Russia, 2I F. (2d) 396, 400, 40I (C. C. A. 2d, I927); The Rogdai, 278 Fed. 294, 296 (N. D. Cal. I920); Agency of Canadian Car \& Foundry Co., Lim., v. American Can Co., 258 Fed. 363, 368-369 (C. C. A. 2d, I9rg); State of Yucatan v. Argumedo, 92 Misc. 547, I57 N. Y. Supp. 2 rg (Ig15) ; I HACK-1 WORTH, Digest of International LAw (I940) $\$ 56$, p. 387 ; Baker, Halleck's INTERNATIONAL LAW (4th ed. I908) 80.

3I. Guaranty Trust Co. v. United States, 304 U. S. 126, I37-138 (1938) ; Lehigh Valley RR. v. State of Russia, 2r F. (2d) 396 (1927); State of Russia v. Banker's Trust Co., 4 F. Supp. 4I7 (S. D. N. Y. 1933).

32. Cases cited note $3 \mathrm{I}$ supra. Mr. Bakhmeteff was Russian Ambassador from July 5, I917 to June 30, 1922. At this time he retired and Mr. Ughet continued to 
The theory is one that has been often observed, ${ }^{33}$ but which was applied in the case of Russia with no apparent awareness of the realities of the situation. While it was perfectly proper to say that the Russian State was always in existence, it was most certainly fantastic to say the State was always represented by a government capable of bringing suit. The fact that the Provisional Government was recognized by the United States until I933 may have prevented the courts from admitting the existence of the controlling Soviet government during that period and may have forced them to entertain suits by ambassadors of the Provisional Government. ${ }^{34}$ However, after recognition of the Soviet régime in 1933 there seems no compelling reason for the courts to any longer ignore the real conditions which were existing before I933. It is true that if the courts now say the Soviet government was the real government of Russia during most of the time we recognized the Provisional Government, they are, in effect, contradicting the then determination of the United States political departments. Not to say so, however, seems a refusal to give effect to the present determination of our political departments, a consideration of the utmost importance. Admitting that the Provisional Government was a mere figurehead and hence not really capable of bringing suit for the Russian State would support the contention that the statute should be tolled. The result is desirable, and shows a consciousness of reality.

\section{c. Nullum Tempus Occurrit Regi}

Another theory, less likely than that of tolling the statute, is based upon the rule nullum tempus occurrit regi ${ }^{35}$ which seems an outgrowth of the old axiom rex non potest peccare. ${ }^{\mathrm{se}}$ The exemption of the king, or government, from the running of the statute of limitations is no longer based on the king's prerogative but on the more practical consideration that the government should not suffer from the negligence of its public officials in not pressing claims promptly. ${ }^{37}$. It is argued that this rule applies not only to the domestic sovereign but also to foreign sovereigns bringing suit in domestic courts, and that the statute of limitations is therefore not applicable to the U. S. S. R. ${ }^{38}$ The contention is not sup-

be recognized by us as the Financial Attache and the custodian of Russian property in the United States.

33. Cases cited notes 30 and $3 I$ supra.

34. In Lehigh Valley RR. v. State of Russia, 2I F. (2d) 396 (I927), the ambassadors of the Provisional government were allowed to sue and collect nearly $\$ 1,000,000 !$ The money was handed over to Mr. Ughet, the representative of the Provisional Government, in spite of the fact that his government had no control and little interest in the actual State of Russia. The case has been properly criticized. See the concurring opinion of Mr. Justice Frankfurter in United States v. Pink, Io U. S. I. WEeK 4I7I, 4I77 (I94I); Kallis, The Legal Effects of the Non-Recognition of Russia (I933) 20 VA. L. REv. I, II.

35. "Time does not run against the king." The rule seems to have originated in U. S. v. Hoar, 26 Fed. Cas. 329, 330 No. 15, 373 (I821). It has been followed in Davis v. Corona Coal Co., 265 U. S. 219 (I924); Grand Trunk Western Ry. v. United States, 252 U. S. II2 (I920); Ash's Estate, 202 Pa. 422, 51 Atl. I030 (I902); PUente, Internatronal Law (1928) 84.

Note that the cases involve only the domestic sovereign. (I880).

36. "The king can do no wrong." See County of Piatt v. Goodell, 97 I11. 84, 88

37. United States v. Thompson, 98 U. S. 486, 489 (I878); United States v. Knight, I4 Pet. 30I, 3 I5 (U. S. I840); United States v. Kirkpatrick, 9 Wheat. 720, 735 (U. S. I824).

38. This contention was successfully asserted in United States v. Guaranty Trust Co., 9I F. (2d) 898 (C. C. A. 2d, I937), commented on in (1938) 5 U. of CHI. L. REV. 313 and (I937) 47 YALE L. J. 132. 
ported by either precedent or the reason for the rule. The only authority favoring the extension of this rule seems to be the dicta of Mr. Justice Story in United States $v$. Hoar" ${ }^{39}$ that the royal prerogative is "equally applicable to all governments". Since the rule is framed to protect the sovereign from the negligence of public officials, there is no reason why it should be employed for the protection of a foreign sovereign against the negligence of its servants. That is a matter strictly for its own consideration.

The problem of whether or not the United States should be barred when suing as assignee of a foreign sovereign against whom the statute had run was raised in the Guaranty Trust Company case. The court held that the bar applied for the same reason it applied to a foreign sovereignthe reason behind the rule exempting the United States fails when the United States is assignee for as such its own servants could not have been negligent. ${ }^{40}$

Today the protective rule is becoming more and more limited in its application to the domestic sovereign. Several states have passed laws specifically removing themselves from this exemption. ${ }^{41}$ It seems a wise move since both state and national governments have competent legal departments to prosecute their claims, and exemption from the consequences of the statutes of limitation may well do the government more harm than good, for its tendency is to promote laxity in the assertion of claims.42

\section{d. The Retroactive Effect of Recognition}

As a general proposition it may be said that the acts of a sovereign may not be questioned provided they are completed within the sovereign's jurisdiction. ${ }^{43}$ This is only true, however, of a recognized sovereign, for non-recognition is usually the unfortunate result of disapproval by the non-recognizant country. ${ }^{44}$ Until recognition a foreign nation cannot be considered the equal of all other nations, and until then does not have jurisdictional immunity. ${ }^{45}$ After recognition, however, all acts within the jurisdiction of the recognized nation are considered valid whether they have been performed before recognition or afterward. This result is accomplished by the doctrine of retroactive recognition, which was expressed by the Supreme Court in Oetjen v. Central Leather Company: ${ }^{46}$

"It is also the result of the interpretation by this court of the principles of international law that when a government which orig-

39. 26 Fed. Cas. 329,330 , No. I5,373 (I82I). This dictum may be found in Fink v. O'Neil, I06 U. S. 272, 28I (I882); United States v. Thompson, 98 U. S. 486, 490 (I878); Gibson v. Chouteau, 13 Wall. 92, 99 (U. S. I87I).

40. 304 U. S. I26, I4I (I938). Note that the court did not apply the usual rule that the assignee stands in the shoes of his assignor. Southern Pacific Co. v. Globe Indeminity Co., 2I F. (2d) 288, 290 (I927).

4I. 2 MASS. GEN. LAWS (I932) c. 260, § I8; 4 Mont. Rev. Codes (1935) § 9043 ;

I Mo. Rev. Stat. (r929) \$888; N. Y. CIV. PRAC. ACT (Cahili, 6th ed. I93I) § 54.

42. For this suggestion see (1937) 47 YALE L. J. I32.

43. Guaranty Trust Co. v. United States, 304 U.. S. I26, I40 (1938); Oetjen v. Central Leather Co., 246 U. S. 297, 303 (I9I8); Day-Gormley Leather Co. v. National City Bank of New York, 8 F. Supp. 503 (S. D. N. Y. 1934); Princess Paley Olga v. Weisz, (I929) I K. B. 718.

44. Gelston v. Hoyt, I3 Johns. 56i, 588 fn. (a) (N. Y. I8I6); I: O'ppenherar, International Law (5th ed. 1937) \$73, p. i24; PUente; International Law (I928) 27.

45. Stockton, Outhines of International Law (IgI4) 87.

46. 246 U. S. $297 ; 302-303$ (I918).

"It is incompetent for them (the courts) to anticipate the political departments; but once recognition has been granted the courts may treat it as oper- 
inates in revolution or revolt is recognized by the political department of our government as the de jure government of the country in which it is established, such recognition is retroactive in effect and validates all the actions and conduct of the government so recognized from the commencement of its existence."

This doctrine was conceived so that the courts would be relieved of the embarrassing duty of passing upon the rightfulness or wrongfulness of the acts of a now recognized sovereign, which duty would be equally painful, and dangerous, whether the acts were committed before or after recognition." The element of "fair play" also enters into the courts' consideration of retroactivity. If acts done prior to recognition were ineffective, the now recognized government would often be deprived of rightful property and interests. ${ }^{48}$

All the cases which have thus far employed the doctrine of retroactivity appear to involve some act or acts done by the sovereign during its period of non-recognition. We are presently concerned with the application. of this doctrine when the sovereign has failed to act-when it did not bring its action within the statutory period. How should it be applied in such a situation?

Counsel for the Government in the Guaranty Trust Company cases suggested the doctrine would make the recognition of the former Provisional Government of Russia and all acts of that government void. This would support counsel's contention that there was no recognized government in Russia capable of bringing suit and therefore the statute of limitations should be tolled. The court properly refused to employ the doctrine in this manner on the ground that recognition retroactively affected only those acts of the recognized government done within its jurisdiction. $\$$ Having thus disposed of counsel's suggestion the court did not further dwell upon the matter of retroactivity.

There are, however, further possibilities the court might have considered. It could have held that the doctrine applied only to acts and therefore could not be used here, but this would seem to be merely avoiding the problem. Another possibility would be to apply the doctrine with the effect that the U. S. S. R. is considered a recognized government from its very inception in IgI8. It would therefore follow logically that the

ative $a b$ initio and so take account of the unrecognized de facto government or state which existed prior to the political department's action. By means of this fiction, the judiciary has frequently found it possible to do justice in matters of private right without becoming involved in political questions." Dickinson, The Unrecognized Government or State in English and American Law (I923) 22 Mich. L. REv. 29, 44.

Cases supporting the doctrine of retroactivity are: United States v. Belmont, $30 I$ U. S. 324, 330 (I937) ; Ricaud v. American Metal Co., Lim., 246 U. S. 304, 309 (Igr8) ; Underhill v. Hernandez, 65 Fed. 577 (C. C. A. 2d, I895), aff'd, I68 U. S. 250, 253 (1897) ; Williams v. Bruffy, 96 U. S. I76, I86; Aksionairnoye Obschestvo Dlia Mechanicheskoyi Obrabotky Diereva A. M. Luther v. Sagor \& Co. generally cited as Luther v. Sagor, (I92I) $3 \mathrm{~K}$ B. 532. See also I HACKworTH; Digest of International Law (1940) 38I; Hervey, Legal Effects of RecogniTION IN INTERNATIONAL LAW (i928) 82.

47. State of Yucatan v. Argumedo, 92 Misc. 547, 553-554, I57 N. Y. Supp. 219, 224-225 (I9I5); HERVEX, op. cit. stupra note 46; quotation from Dickinson, loc. cit. sispra note 46 .

48. Dickinson, loc. cit. supra note 46.

49. 304 U. S. 126, I40 (1938). See Vladikavkazky Ry. v. New York Trust Co., 263 N. Y. 369 , 379, I89 N. E. 456, 460 (I934); Lehigh Valley RR. v. State of Russia, 2 I F. (2d) 396, 40 I (C. C. A. 2d, rg27). 
U.S. S. R. is also considered as having been able to sue within the proper time, and since it did not, the statute of limitations is a bar.

However, the courts might have said the doctrine of retroactivity validates all prior jurisdictional acts of the recognized government and starts the running of the statute from the moment of recognition, thus reaching an opposite conclusion.

\section{Policy}

The theories discussed above are little more than legal by-paths over which the courts travel in order to reach a result which will best make effective the determinations of the government's political departments. The broad base of international law is undeniably a matter of policy.

The policy of non-recognition of the U. S. S. R., pursued by the United States from I9I8 to $1933,{ }^{50}$ has been criticized. ${ }^{51}$ It was most certainly a departure from the usual United States policy, ${ }^{52}$ based on long historical precedent, of according prompt recognition as soon as a new government had achieved sufficient stability. ${ }^{63}$ It created a huge mass of insurmountable legal and diplomatic difficulties. ${ }^{54}$ Prompt recognition would have paved the way for negotiations and differences could have been adjusted far more quickly and easily. ${ }^{55}$ It has quite properly been said that:

"The interests of the old States must suffer quite as much as those of the new State, if recognition is for any length of time refused." 56

Now that the Soviet government is recognized by the United States we should make that recognition as advantageous as possible. To bar the U. S. S. R. from suit because it was previously unable to sue is to give effect to the repudiated policy of non-recognition. The District Court in

50. The policy was maintained because the United States contended that the Soviet government was:

". . . deficient in its observance of the fundamental conditions of international intercourse in three respects, namely:

(I) Its failure to accord to the persons and property within its jurisdiction that degree of respect and protection required by international law;

(2) Its failure to respect the international obligations of preceding governments; and

(3) Its failure to respect the right of other nations to develop their institutions and to conduct their internal affairs without interference or control by other states."

Hackworth, The Policy of the United States in Recognizing New Governments During the Past Twenty-Five Years (I93I) Ans. Soc. INT. L. Proc. I20, I3I.

5I. See Dickinson, The Recognition of Russia (I93I) 30 MICE. L. REv. I8I. Contra: (1933) 27 AMr. J. INr. L. 290.

52. "We surely cannot deny to any nation that right whereon our own Government is founded-that every one may govern itself according to whatever form it pleases, and change these forms at its own will .. . " Letter from Thomas Jefferson to Governeur Morris quoted in I MOORE, International LaW Digest (Ig06) I20.

53. I MOORE, Internatronal Law Digest (1906) II9; Dickinson, loc. cit. supra note 5I; Hackworth, The Policy of the United States in Recognizing Neze Governments During the Past Twenty-Five Years (I93I) Ans. Soc. INT. L. Proc. I20.

54. "Whenever an act done by a sovereign in his sovereign character is questioned it becomes a matter of negotiation, or of reprisals, or of war." Judge Andrews in Wulfsohn v. R. S. F. S. R., 234 N. Y. 372, 376, 138 N. E. 24, 26 (I923). See also United States v. Diekelman, 92 U. S. 520, 524 (I875).

55. See Dickinson, loc. cit. supra note $5 \mathrm{I}$; Graham, Russian-American Relations, 19I7-I933: An Interpretation (I934) 28 AM. PoL. Scr. REv. 387.

56. I OPRENHEIM, INTERNATIONAL LAW (5th ed. I937) \&72, p. I24. 
the National City Bank case said the statute of limitations must be held to have run for otherwise ". . . one of the most effective sanctions of non-recognition would lose most of its value." 57 This seems to completely ignore the fact that recognition thus loses much of its value, and recognition is the policy the courts should now make effective.

It may be argued that it is inconsistent to say an unrecognized government cannot sue and yet toll the statute of limitations during that period of disability. However, we must take into consideration an important factual situation. While the foreign sovereign is unrecognized the courts cannot allow it to sue because they are bound by the policy of our political departments. Now, however, the attitude of the political departments has changed-the foreign sovereign is recognized. Is it not then wise for the attitude of our courts to change and no longer give effect to an outmoded policy? This would seem to be the most reasonable and wisest treatment that could be accorded the Soviet régime.

\section{CONCLUSION}

As a matter of policy it therefore seems clear that the best result will be achieved by not barring the Soviet actions. Several legal theories may be applied to make this policy effective. Non-recognition may be considered a disability tolling the statute of limitations. It will, of course, have to be admitted that the Provisional Government did not really represent the Russian State but that the Soviet government was in control. The doctrine of retroactivity could be applied so that the statute only started running from the moment of recognition. Perhaps the statute should not be available as a defense on the ground that the defendant, as a citizen of the United States and hence part of its government, was instrumental in causing it to run. Regardless of which theory is used to reach the conclusion that the U. S. S. R. is not barred by the statute of limitations, it is clear that such conclusion is the desirable one for it is supported by all important considerations of policy.

M. L. H.

57. 4I F. Supp. 353, 355 (S. D. N. Y. I94I). 